\title{
Effect of Cooking on Cooking Time, Nutritional Content and Sensory Properties of Pawpaw-treated Bambara Groundnut
}

\author{
Joseph Ahima, Agnes Amissah, John Owusu*, Ebenezer Nartey \\ Faculty of Applied Science and Technology, Hospitality Department, Koforidua Polytechnic, P. O. Box 981, Koforidua, \\ Ghana. \\ Email:jkowusugh@yahoo.com*
}

\begin{abstract}
Cooking of bambara groundnut is time and energy consuming. This research was therefore carried out to find a way of reducing the cooking time of bambara groundnut and at the same time reduce losses of nutrients. Green pawpaw slices, both fresh and dried were added to the raw bambara groundnut and cooked. The treated Bambara groundnut recorded the lowest cooking time $(\mathrm{P}<0.05)$ compared with the untreated. The treatment did not have any effect $(\mathrm{P}<0.05)$ on the calcium, and phosphorous contents, but rather led to increased levels $(\mathrm{P}<0.05)$ of crude protein, crude fat and iron but reduced levels of carbohydrate, crude fibre and ash content. However, the untreated Bambara groundnut gave the best sensory properties and hence the best overall acceptability. The findings of the research when applied, has the potential to reduce fuel consumption and conserve the environment.
\end{abstract}

Keywords: Green pawpaw; Bambara groundnut; cooking; dry pawpaw slices; crude.

\section{Introduction}

Meat consumption is known to be accompanied by an increased intake of saturated fat and cholesterol. In addition, meat protein is expensive. These have probably led to an increased emphasis on the use of plants as a source of protein, especially in developing countries. The major source of plant proteins are legumes, nuts and cereal grains. Bambara groundnut is a typical example of a legume that can be consumed in different forms either in the immature green state or matured form. On the average, the matured seeds of bambara groundnut contain11.6g moisture, $3.61 \mathrm{~g}$ ash, $19.7 \mathrm{~g}$ protein, $57.9 \mathrm{~g}$ carbohydrates, and $5.90 \mathrm{~g}$ fat $/ 100 \mathrm{~g}$ (dry weight) respectively (Kaptso et al., 2008). The gross energy value of bambara groundnut is greater than that of other common pulses such as cowpea, lentil and pigeon pea (FAO, 2001). Bambara groundnut has no cholesterol, is a good source of fiber, and a source of plentiful supply of thiamine (Vitamin $\mathrm{B}_{1}$ ) and some minerals (Brough and AzamAli, 1992). The main essential amino acids in bambara groundnut are lysine and leucine (Mune et al., 2011).

The anti-nutritional (such as trysin inhibitors) and toxic factors found in legumes interfere with normal growth of animals and humans. However, these can be inactivated by cooking or by controlled heating during processing (King et al., 1985). Proteins in legumes coagulate during cooking, and become more available (Milner, 2000). Therefore, cooking is an important processing method for legumes. Bambara groundnut is hard to cook, and therefore requires a longer period of cooking time and invariably higher consumption of energy. Higher energy consumption has implications for the environment, as more fuel or electricity is used during the cooking process. Due to its hardness, bambara groundnut is usually given some form of pretreatment before it is cooked in order to reduce the processing time and energy consumption. The pretreatment methods include steeping in cold water overnight, and the addition of baking soda or saltpeter during cooking. Steeping leads to the imbibing of water by bambara groundnut, making it slightly tender before cooking, and this reduces the cooking time and the flatulence factor (Gates, 1987). However, it leads to nutrient losses, especially minerals and water-soluble vitamins (Garcua-Pascual et al., 2006).

The use of baking soda or saltpetre also reduces the processing time, but leads to the loss of some vitamins (especially thiamin) and causes stomach discomfort in some individuals. 
Pawpaw (Carica papaya) is a source of the enzyme,papain (Azarkan et al., 2003). Papain belongs to a family of related proteins with a wide variety of activities, including endo-peptidases, amino peptidases, dipeptidyl peptidases and enzymes with both exo-and endo-peptidase activity (Rawlings and Barrett, 1994). It is known that papain attacks the protein in meats and breaks it down to make it tender (Bender, 2005).It is therefore hypothesized that the enzyme (papain) in the slices of unripe pawpaw could similarly attack the proteins in bambara groundnut during cooking to make it tender. The research was therefore carried out to determine the effect of the activities of the papain in green pawpaw slices on the cooking time of bambara groundnut, and to assess the nutritional composition of the cooked bambara groundnut as well as to evaluate its consumer acceptability.

\section{Materials and methods}

\subsection{Source of material}

Unripe pawpaw was obtained from the Ministry of Food and Agriculture (MOFA) at Kwabeng in the Eastern Region of Ghana. Bambara groundnut was purchased from the Makola market in Accra, Ghana.

\subsection{Processing of bambara groundnut}

The bambara groundnut was sorted to remove stones, twigs, and dirt. They were then washed several times under running tap water and dried with paper napkin. Three replicates of $200 \mathrm{~g}$ each were weighed for each treatment using a top loading balance (Top Pan Balance, AC-260, India). A ratio of 1:6 (w/v) of beans to distilled water were placed in a saucepan, and put on a gas cooker. The distilled water was initially at room temperature $\left(27^{\circ} \mathrm{C}\right)$, and the temperature gradually rose up as cooking progressed. During cooking, temperature was monitored using a digital thermometer (Test Products International Inc., Beaverton, OR 97005). A stop-clock was used to check the cooking time, and the end of cooking was determined by squeezing the beans in between the thumb and fingers. When felt soft between the thumb and fingers, the bambara groundnut was considered to be well cooked, the stop-clock was switched off, and the time (min) recorded. This subjective method of determining the cooking time had been used by several previous authors (Vindiola et al., 1986; Mazahib et al., 2013; Kinyanjui et al., 2015). The various treatments used for the experiments were; Bambara groundnut with fresh pawpaw slices (D), bambara groundnut with dried pawpaw slices (A), and untreated bambara groundnut (E-Control). The weight of the pawpaw slices used in each case was $20 \mathrm{~g}$.

\subsection{Nutritional analysis of samples}

The nutritional composition of bambara groundnut of different treatments were carried out using Official Methods of Analysis (AOAC, 1980). All analyses were made in triplicates.

\subsection{Statistical analysis}

Statistical Analysis was carried out using Complete Randomized Design (CRD) with SPSS Version 10. A p-value of less than 0.05 was considered statistically significant.

\subsection{Sensory evaluation of cooked groundnut}

Sensory evaluation of the various processed bambara groundnut was done using a-30 member semi-trained panelists. The panelists were asked to assign scores to their preferences for the various attributes using a seven (7) point hedonic scale, with 1 being like extremely, 2 like very much, 3 like much, 4 neither like nor dislike, 5 dislike much, 6 dislike very much and 7 dislike extremely. The attributes considered were appearance, flavour, taste, mouth feel, after taste, colour and overall acceptability.

\section{Results and discussion}

\subsection{Cooking time and nutritional analysis of cooked beans}

The results of the cooking time for the various treated bambara groundnut is shown in Fig 1. The pawpaw treated Bambara groundnut took a shorter time to cook $(\mathrm{P}<0.05)$ than the control. The pawpaw slices are known to contain papain (Azarkan et al., 2003), and this might have attacked the peptide bonds in the proteins of the Bambara groundnut (Lopes et al., 2007) during cooking, leading to reduced cooking time compared to the control. The cooking time for the fresh pawpaw-treated bambara groundnuts was 


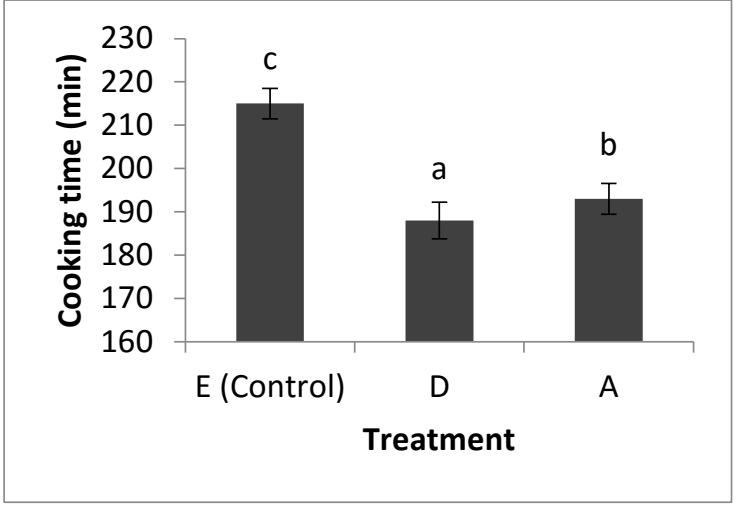

Fig. 1: Cooking time for cooked bambara groundnut (different alphabets show that the treatments are significantly different at $\mathrm{P}<0.05)$.

significantly shorter $(\mathrm{p}<0.05)$ than the one treated with dried pawpaw. The drying of the pawpaw slices might have led to reduced activity of the enzyme, papain.
Seen and Sridhar (2005) reported significant difference in cooking time based on variety of legumes.

The results of the proximate and mineral composition are shown in Table 1. The control sample gave the lowest moisture content $(\mathrm{P}<0.05)$ compared with the treated samples. This is probably because the action of papain on the peptide bonds in the pawpaw treated samples might have enhanced their water holding capacity. The moisture content of the pawpaw treated bambara groundnut was higher than what was reported earlier for beans soaked in water before cooking (Bhagya et al., 2009). The concentration of crude protein and crude fat of the pawpaw treated bambara groundnuts were significantly higher $(\mathrm{P}<0.05)$ in comparison with the

Table 1

Proximate and mineral composition of processed bambara groundnut

\begin{tabular}{lccc}
\hline Component & E (Control) & D & A \\
\hline Moisture $g / 100 g$ dry weight & $9.55 \pm 0.32^{\mathrm{a}}$ & $9.70 \pm 0.33^{\mathrm{b}}$ & $9.90 \pm 0.20^{\mathrm{b}}$ \\
Crude protein (g/100g dry weight) & $19.97 \pm 0.27^{\mathrm{a}}$ & $21.70 \pm 0.25^{\mathrm{b}}$ & $21.60 \pm 0.30^{\mathrm{b}}$ \\
Crude Fat (g/100g dry weight) & $11.97 \pm 0.28^{\mathrm{a}}$ & $12.50 \pm 0.30^{\mathrm{b}}$ & $12.45 \pm 0.31^{\mathrm{b}}$ \\
Ash (g/100g dry weight) & $3.37 \pm 0.20^{\mathrm{c}}$ & $2.49 \pm 0.21^{\mathrm{a}}$ & $2.65 \pm 0.24^{\mathrm{b}}$ \\
Crude fiber (g/100g dry weight) & $3.75 \pm 0.35^{\mathrm{c}}$ & $3.02 \pm 0.41^{\mathrm{a}}$ & $3.20 \pm 0.11^{\mathrm{b}}$ \\
Carbohydrate (g/100g dry weight) & $51.39 \pm 0.34^{\mathrm{c}}$ & $50.59 \pm 0.21^{\mathrm{b}}$ & $50.20 \pm 0.21^{\mathrm{a}}$ \\
Iron (mg/100g) & $1.92 \pm 0.00^{\mathrm{a}}$ & $2.30 \pm 0.21^{\mathrm{c}}$ & $2.12 \pm 0.10^{\mathrm{b}}$ \\
Calcium (mg/100g) & $0.20 \pm 0.11^{\mathrm{a}}$ & $0.22 \pm 0.00^{\mathrm{a}}$ & $0.21 \pm 0.01^{\mathrm{a}}$ \\
Phosphorus (mg/100g) & $0.23 \pm 0.10^{\mathrm{a}}$ & $0.25 \pm 0.16^{\mathrm{a}}$ & $0.24 \pm 0.30^{\mathrm{a}}$ \\
\hline
\end{tabular}

The values are mean \pm standard deviation, different superscripts in a row are significantly different $(\mathrm{P}<0.05)$ untreated.

Previous findings of some authors showed that cooked beans had more crude proteins than the raw beans (Alonso et al., 2000; Shiga et al., 2009; Abdulsalami and Sheriff, 2010). The destruction of certain anti nutritional agents by heat might have led to increased availability of these nutrients. The carbohydrate content of the cooked pawpaw treated beans was significantly lower $(\mathrm{P}<0.05)$ than the raw beans. Similar results were reported by Ramadan (2012). The reduction may be as a result of leaching of soluble nutrients into the cooking medium during cooking. The present results were however, in contrast with those reported by Mazahib et al. (2013).

The ash content of the control was higher $(\mathrm{P}<0.05)$ than that in the pawpaw treated samples. Similar results were reported by other authors (Bhagya et al., 2009; Shiga et al., 2009; Ramadan, 2012). The crude fibre content of the raw beans was higher $(\mathrm{P}<0.05)$ than that in the cooked beans. These findings are similar to the previous ones reported (Shiga et al., 2009; Mazahib et al., 2013). Crude fat value of the cooked bambara groundnut was higher $(\mathrm{P}<0.05)$ than the control. Mazahib et al. (2013) also reported similar results. The iron contents of the treated samples were higher $(\mathrm{P}<0.05)$ than the control, in conformity with the results reported by Shiga et al. (2009). However, the calcium and phosphorus contents of the treated and untreated bambara groundnut were statistically not different $(\mathrm{P}>0.05)$. Thus, the treatment did not have any effect $(\mathrm{P}>0.05)$ on the content of these minerals. 


\subsection{Sensory evaluation}

The sensory attributes of the cooked beans considered in the study were appearance, flavor, taste, mouthfeel, , after taste, colour and over all acceptability. The results of the sensory evaluation of the cooked beans are presented in Table 2 .

Table 2

Sensory scores of the processed bambara groundnut

\begin{tabular}{lccc}
\hline Attributes & & Treatment \\
\cline { 2 - 4 } & E (Control) & $\mathrm{D}$ & $\mathrm{A}$ \\
Appearance & $2.33^{\mathrm{a}}$ & $2.57^{\mathrm{c}}$ & $2.45^{\mathrm{b}}$ \\
Flavour & $2.24^{\mathrm{a}}$ & $2.42^{\mathrm{b}}$ & $2.40^{\mathrm{b}}$ \\
Taste & $2.48^{\mathrm{a}}$ & $2.80^{\mathrm{c}}$ & $2.60^{\mathrm{b}}$ \\
Mouth feel & $2.60^{\mathrm{a}}$ & $2.71^{\mathrm{b}}$ & $2.70^{\mathrm{b}}$ \\
After taste & $2.20^{\mathrm{a}}$ & $2.47^{\mathrm{b}}$ & $2.40^{\mathrm{b}}$ \\
Colour & $2.13^{\mathrm{a}}$ & $2.32^{\mathrm{c}}$ & $2.25^{\mathrm{b}}$ \\
Overall acceptability & $2.41^{\mathrm{a}}$ & $2.80^{\mathrm{c}}$ & $2.52^{\mathrm{b}}$ \\
\hline
\end{tabular}

The values are mean \pm standard deviation, different superscripts in a row are significantly different (P<0.05)

The control sample was the most preferred $(\mathrm{P}<0.05)$ in terms of all the attributes evaluated. In addition, it recorded the best overall acceptability by the panelists. The addition of the pawpaw slices might have imparted taste, appearance, colour, mouthfeel, and flavour to the cooked bambara groundnut, which were not liked much by the panelists compared to the untreated. Appearance, taste, colour, and the overall acceptability ranked lowest for sample $\mathrm{D}(\mathrm{P}<0.05)$.

\section{Conclusions}

This study was carried out to determine whether the use of pawpaw slices as a source of papain can help reduce cooking time. The results indicated that, using pawpaw slices (whether fresh or dry) in cooking bambara groundnut can significantly reduce the cooking time. Even though there were losses of some nutrients, the treatment generally conserved most of the nutrients of the bambara groundnut analyzed. Pawpaw slices treatment of bambara groundnut have the potential to reduce cooking time, conserve energy and maintain some nutritive value, but gave cooked samples of less desired sensory properties.

\section{Acknowledgement}

The authors are grateful for the financial support received from the Applied Research Fund of Koforidua Polytechnic, Ghana.

\section{References}

Abdulsalami, M. S., and Sheriff, H. B. (2010). Effect of processing on the proximate composition and mineral content of bambara groundnut (Voandezeia subterranean). Bayero Journal of Pure and Applied Science, Vol 3 No 1, pp 188-190.

Alonso, R.., Aguirre, A., and Marzo, F. (2000). Effects of extrusion and traditional processing methods on antinutrients and in vitro digestibility of protein and starch in faba and kidney beans. Food Chemistry, Vol 68, pp 159-165.

AOAC (1980). Official Methods of Analysis.13 ${ }^{\text {th }}$ ed .Washington DC, Association Official Analytical Chemists.

Azarkan, M., El Moussaoui, A., van Wuytswinkel, D., Dehon, G., and Looze, Y. (2003). Fractionation and purification of the enzymes stored in the latex of Carica papaya. Journal of Chromatography B, Vol 790, pp 229-238.

Bender, D. A. (2005). Papain: A Dictionary of Food andNutrition.Encyclopedia.com.http://www.ency clopedia.com/doc/1O39-papain.html. Accessed on $21^{\text {st }}$ May, 2014

Bhagya, B., Sridhar, K. R., Raviraja, N. S., Young, C. C., and Arun, A. B. (2009). Nutritional and biological qualities of the ripened beans of Canavalia maritime from the coastal sand dunes of India. Comptes Rendus Biologies, Vol 332, pp 2533. 
Brough, S.H., and Azam-Ali, S. N. (1992). The effect of soil moisture on the proximate composition of bambara groundnut (Vigna subterranean L) Verdc. Journal of the Science of Food and Agriculture, Vol 60, pp 197-203.

FAO (2001). Agricultural and Horticultural Seeds. FAO Agricultural Studies No. 55.

Garcua-Pascual, P., Sanjua'n, N., Ricardo M. R., and Mulet, A. (2006). Morchella esculent (morel) rehydration process modeling. Journal of Food Engineering, Vol 72, pp 346-353.

Gates, J. C. (1987). Basic Foods. 3rd ed. Library of Congress Cataloging -in- Publication data, Harcourt Brace Javanovich College Publishers. U.S.A.

Kaptso, K. G., Njintang, Y. N., Komnek, A. E., Hounhouigan, J., Scher, J., and Mbofung, C. M. F. (2008). Physical properties and rehydration kinetics of two varieties of cowpea (Vigna unguiculata) and bambara groundnuts (Voandzeia subterranean) seeds. Journal of Food Engineering, Vol 86, pp 91-99.

King, J., Nnanyelugo, D. O., Ene-Obong, H. N., Ngoddy, P.O. (1985). Household consumption profile of cowpea (Vigna unguiculata) among low income families of Nigeria. Ecology of Food and Nutrition, Vol 16, pp 209- 221.

Kinyanjui, P. K., Njoroge, D. M., Makokhal, A. O., Christiaens, S., Ndakal, D. S., and Hendrickx, M. (2015). Hydration properties and texture fingerprints of easy- and hard-to-cook bean varieties. Food Science and Nutrition, Vol 3 No 1, pp 39- 47.

Lopes, M. C., Mascarini, R. C., da Silva, B. M., Flório, F. M., Basting, R. T. (2007). Effect of a papainbased gel for chemomechanical caries removal on dentine shear bond strength. Journal of Dentistry for Children (Chicago), Vol 74, No 2, pp 93-97.

Mazahib, A. M., Nuhu, M. O., Salawa, I. S., and Babiker, E. E. (2013). Some nutritional attributes of bambara groundnut as influenced by domestic processing. International Food Research Journal, Vol 20, No 3, pp 1165-1171.

Mune, M. A., Minka, S. R., Lape M. I., and Etoa, F. X. (2011). Nutritional potential of bambara bean protein concentrate. Pakistan Journal of Nutrition, Vol 10, pp 112-119.

Milner, J. A. (2000). Functional foods: the US perspective. The American Journal of Clinical Nutrition, Vol 71 (6), pp 1658 - 1662.

Ramadan, E. A. (2012). Effect of processing and cooking methods on chemical composition, sugars, and phytic acids of soybeans. Food and Public Health, Vol 2 No 1, pp 11-15.
Rawlings, N. D., Barrett, A. J. (1994). Families of cysteine peptidases. Methods in Enzymolysis, Vol 244, pp 461-486

Seena, S., and Sridhar, K. R. (2005). Physicochemical, functional and cooking properties of under explored legumes, Canavalia of the southwest coast of India. Food Research International, Vol 38, pp 803-814.

Shiga, T. M., Cordenunsi, B. R., and Lajolo, F. M. (2009). Effect of cooking on non-starch polysaccharides of hard-to-cook beans. Carbohydrate Polymers, Vol 76, pp 100-109.

Vindiola, O. L., Seib, P. A., and Hoseney, R. C. (1986). Accelerated development of hard-to-cook state in beans. Cereal Foods World, Vol 31, pp 538-552. 